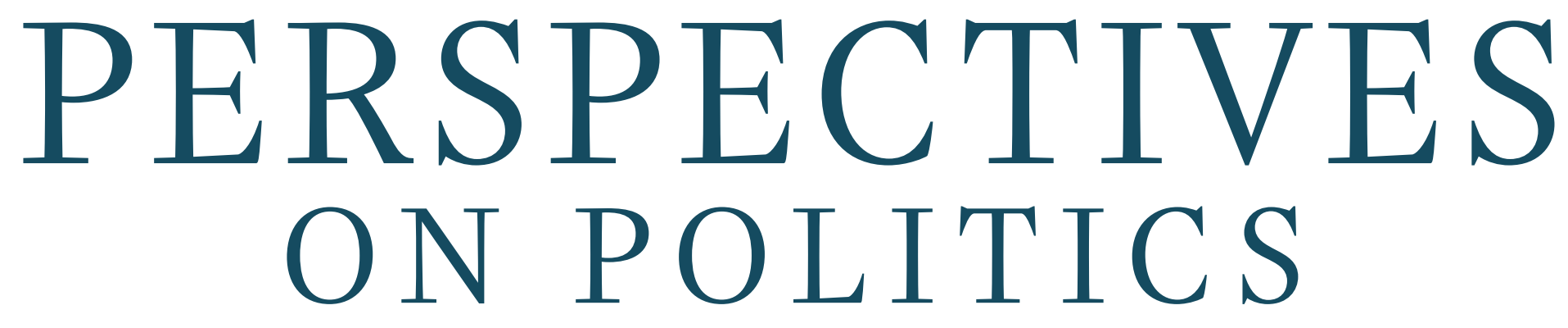

A Political Science Public Sphere | September 2015, Volume 13, Number 3

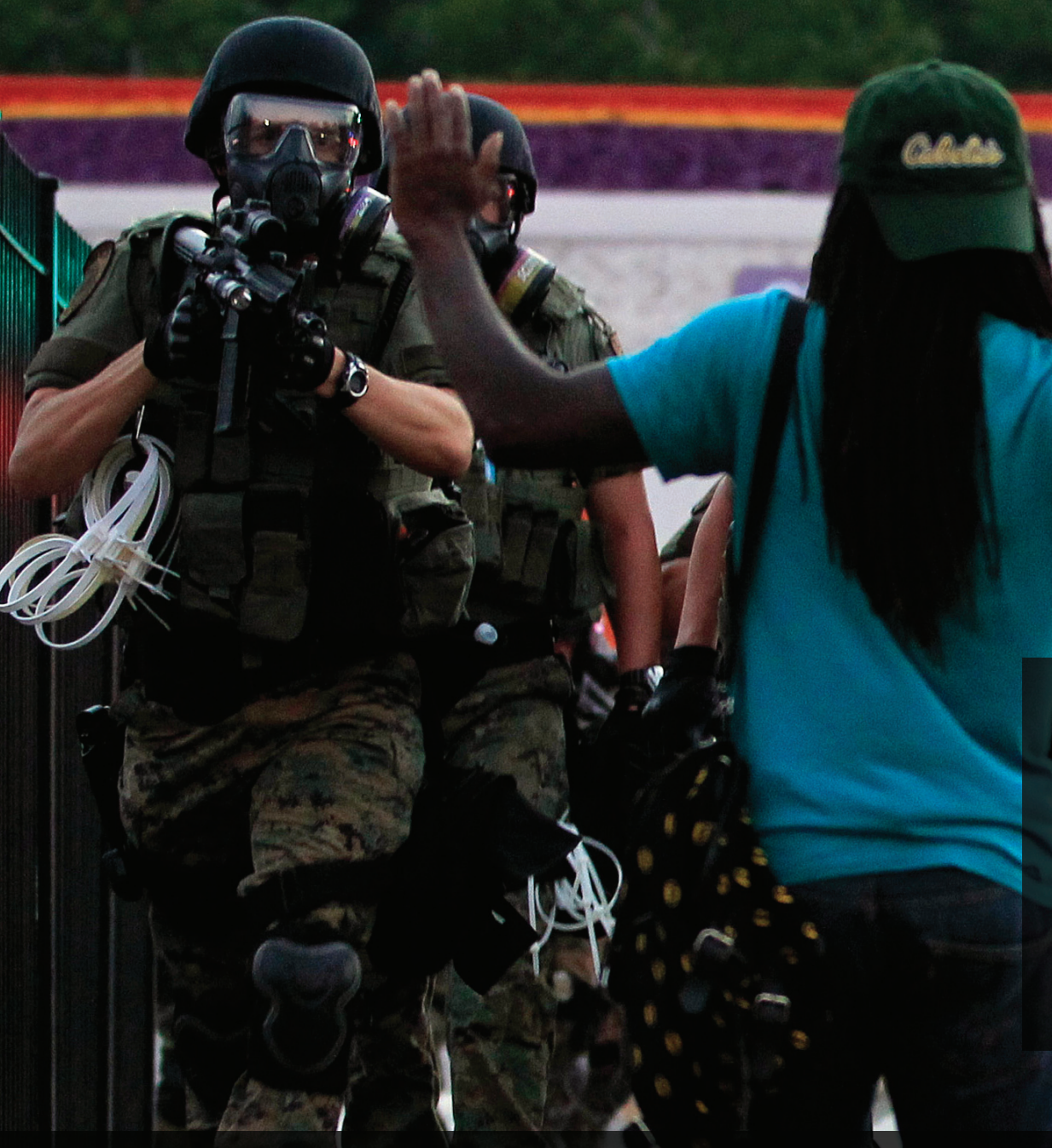

\section{Critical Trialogue: The Carceral State}

Marie Gottschalk, Naomi Murakawa, Amy E. Lerman and Vesla M. Weaver

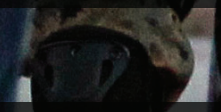

The Rights Revolution in the Age of Obama and Ferguson: Policing, the Rule of Law, and the Elusive Quest for Accountability

Lynda G. Dodd 


\section{$\triangle$ LYNNE RIENNER PUBLISHERS

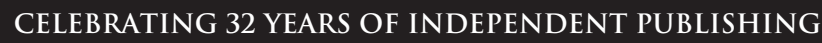

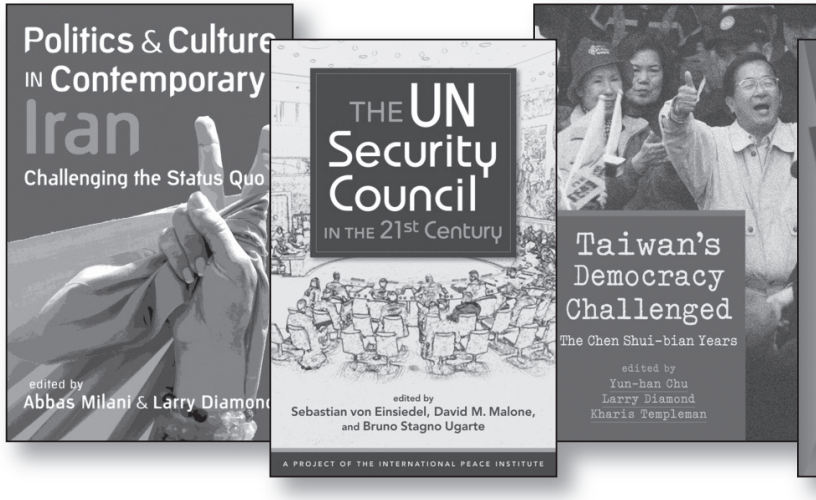

Politics and Culture in Contemporary Iran:

\section{Challenging the Status Quo}

ABbas MILANI AND LARRY DIAMOND, EDITORS

"This finely crafted book ... allows readers to go beyond the official representation of the country and gain a deeper appreciation of the complexity of a rich and vibrant society."-Library Journal • hc $\$ 65 ・ p b \$ 25$

\section{Building Rule of Law in the Arab World:} Tunisia, Egypt, and Beyond

Eva Bellin ANd HeIdI E. LANE, EDITORS

"Important and original.... This rich, insightful work makes an important contribution to the scholarly literature."-Bruce Rutherford, Colgate University • hc $\$ 72$

\section{NOW IN PAPERBACK!}

\section{Power Politics in Zimbabwe}

Michael Bratton

"A powerful and deeply personal book about Zimbabwean politics that also yields considerable comparative insights for students of democracy in other parts of Africa."

-Pierre Englebert, Journal of Democracy • hc $\$ 68 \cdot \mathrm{pb} \$ 25$

NEW-3RD EDITION!

\section{The European Union and the Member States}

Eleanor E. Zeff and Ellen B. Pirro, editors

"Invaluable to all specialists, students, and academics working in the field of European studies and international relations."-Wojciech Woźniak, Journal of Contemporary European Studies • pb $\$ 28.50$

\section{Taiwan's Democracy Challenged:}

The Chen Shui-bian Years

Yun-han Chu, LaRry Diamond, and Kharis Templeman, editors "This volume may become the definitive resource for understanding the Chen Shui-bian era."-Vincent Wei-cheng Wang, University of Richmond • hc $\$ 75 \bullet$ pb $\$ 32.50$

\section{Polarization and the Presidency: From FDR to Barack Obama}

Robert C. Smith and Richard A. Seltzer

"This excellent and judicious book helps explain why US politics has become dysfunctional. Highly recommended.'

-Choice • hc $\$ 68.50$

\section{TH EDITION}

\section{Public Policy: Perspectives and Choices} Charles L. Cochran and Eloise F. Malone

"Offers an excellent mix of policymaking theory and policy case studies, with a solid understanding of the US policy process. Few other textbooks provide such a mix." -Frank C. Thames, Texas Tech University • pb $\$ 35$

\section{The UN Security Council in the $21^{\text {st }}$ Century}

Sebastian von Einsiedel, David M. Malone, AND BRUNO StAGNO UGARTE, EDITORS

"This is likely to be a cornerstone of the scholarly literature on the United Nations.... An essential volume." —David Cortright, University of Notre Dame - hc $\$ 85 \cdot \mathrm{pb} \$ 35$ A Project of the International Peace Institute

\section{Political Islam and Democracy in the Muslim World}

Paul Kubicek

"A 'must read' on Muslim politics.... Professor Kubicek shows that the examination of Islam and democracy should not be restricted to the Middle East." —Ahmet T. Kuru, San Diego State University • hc $\$ 72$

\section{Russia's Far East:}

New Dynamics in Asia Pacific and Beyond

Rensselaer Lee And ArTyom LuKin

"Solidly researched, well written... and makes a real contribution to our understanding of this remote yet important region."-Charles E. Ziegler, University of Louisville • hc $\$ 68$ 


\section{Perspectives on Politics}

September 2015/Vol. 13, No. 3 | American Political Science Association

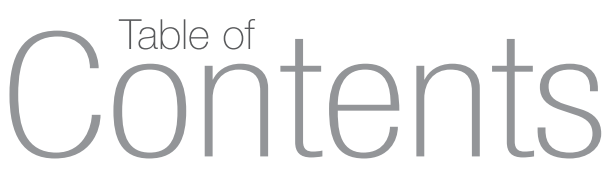

\section{From the Editor}

609 The American Politics of Policing and Incarceration Jeffrey C. Isaac

\section{Articles}

618 Perverse Politics: The Persistence of Mass Imprisonment in the Twenty-first Century Rebecca U. Thorpe

638 Taxing the Poor: Incarceration, Poverty Governance, and the Seizure of Family Resources Mary Fainsod Katzenstein and Maureen R. Waller

657 The Rights Revolution in the Age of Obama and Ferguson: Policing, the Rule of Law, and the Elusive Quest for Accountability

Lynda G. Dodd

680 Ida B. Wells and "Color Line Justice": Rethinking Reparations in Feminist Terms Lawrie Balfour

697 Models of Emergency Statebuilding in the United States Tyler M. Curley

\section{Reflections}

714 Democracy and Education Behind Bars Joshua A. Miller

722 Forensic Intelligence and the Deportation Research Clinic: Toward a New Paradigm Jacqueline Stevens

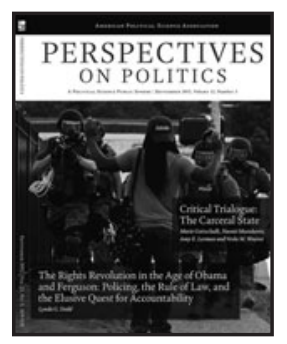

Cover art: Ferguson, MO. Aug. 11, 2014. Police wearing riot gear walk toward a man with his hands raised. The response to Brown's death turned violent because of a convergence of factors, observers said. (AP Photo/Jeff Roberson, File) 
739 Philosophical Hermeneutics and the Politics of Memory

Georgia Warnke

\section{Review Essays}

749 Punitive Politics in the United States: The End of an Era?

Keally McBride

754 Slavery and the Making of American Capitalism Desmond Jagmohan

757 Race, Punishment, and Public Opinion Vincent Hutchings

762 Police Work: The Centrality of Labor Repression in American Political History Alex Gourevitch

774 Policing Democracy: Race, Riots and Protest William Smith

778 The Militarization of Policing and the Future of U.S. Politics Christopher J. Coyne

782 International Politics and the Illicit Global Economy Peter Andreas

\section{Review Symposium}

789 Combating Political Extremism

A discussion of Alexander S. Kirschner's A Theory of Militant Democracy:

The Ethics of Combatting Political Extremism

Cas Mudde

Takis S. Pappas

Nomi Claire Lazar

Giovanni Capoccia

\section{Critical Trialogue}

798 The Carceral State

Reviews and Responses

Amy E. Lerman and Vesla M. Weaver

Arresting Citizenship: The Democratic Consequences of American Crime Control

Naomi Murakawa

The First Civil Right: How Liberals Built Prison America

Marie Gottschalk

Caught: The Prison State and the Lockdown of American Politics 


\title{
Critical Dialogues
}

815 Reviews and Responses Joseph H. Carens

The Ethics of Immigration
Bridget Anderson

Us \& Them? The Dangerous Politics of Immigration Control

\section{Banu Bargu}

Starve and Immolate: The Politics of Human Weapons

Punishment and Inclusion: Race,

Membership, and the Limits of

American Liberalism

826 Reviews and Responses

Neil Roberts

Freedom as Marronage

\author{
Jimmy Casas Klausen \\ Fugitive Rousseau: Slavery, Primitivism, \\ and Political Freedom
}

\section{Book Reviews}

\section{POLITICAL THEORY}

832 Ryan K. Balot, Courage in the Democratic Polis: Ideology and Critique in Classical Athens.

Review by Matthew Landauer

Julie Cooper, Secular Powers: Humility in Modern Political Thought.

Review by Joshua Mitchell

834 Robert Garner, A Theory of Justice for Animals: Animal Rights in a Nonideal World.

Review by Steve Cooke

Adam Gearey, Justice as Welfare: Equity and Solidarity. Review by Sally J. Scholz

837 Margaret Gray, Labor and the Locavore: The Making of a Comprehensive Food Ethic.

Chad Lavin, Eating Anxiety: The Perils of Food Politics.

Review by Patricia Cavanaugh

Geoffrey Hawthorn, Thucydides on Politics: Back to the Present. Review by Eric Buzzetti

840 Lisa Herzog, Inventing the Market: Smith, Hegel, and Political Theory. Review by Tom Hoffman

James D. Ingram, Radical Cosmopolitanism. Review by Shannon Brincat

843 Neal Leavitt, The Foreign Policy of John Rawls and Amartya Sen. Review by David A. Reidy

845 Tracy Lightcap and James P. Pfiffner, Examining Torture: Empirical Studies of State Repression. Review by Will H. Moore

847 Arthur M. Melzer, Philosophy Between the Lines: The Lost History of Esoteric Writing. Review by David Thunder

848 Austin Sarat, Civility, Legality, and Justice in America. Review by Sara Rushing

850 Nichole Marie Shippen, Decolonizing Time: Work, Leisure, and Freedom. Review by Nancy S. Love

851 Adrian Vermeule, The Constitution of Risk. Review by Peter Stone

853 Mark Wenman, Agonistic Democracy: Constituent Power in the Era of Globalization. Review by Nancy Luxon

854 Jude Browne, Dialogue, Politics and Gender.

Alison M. Jaggar, Gender and Global Justice. Review by Maria Rosales

856 Martha C. Nussbaum, Political Emotions: Why Love Matters for Justice. Review by Michael E. Morrell 
AMERICAN POLITICS

858 Julia R. Azari, Delivering the People’s Messsage: The Changing Politics of the Presidential Mandate.

Review by Jeffrey P. Mehltretter Drury

859 Paul Burstein, American Public Opinion, Advocacy, and Policy in Congress: What the Public Wants and What It Gets. Review by Jason Barabas

861 Timothy J. Conlan, Paul L. Posner, and David R. Beam, Pathways of Power: The Dynamics of National Policymaking.

Review by Matt Grossmann

862

Michele Landis Dauber, The Sympathetic State: Disaster Relief and the Origins of the American Welfare State. Review by Eileen McDonagh

863 Jeffrey Mehltretter Drury, Speaking with the People's Voice: How Presidents Invoke Public Opinion. Review by Julia R. Azari

864 Stephen M. Feldman, Neoconservative Politics and the Supreme Court: Law, Power and Democracy. Review by J. Mitchell Pickerill

866 Erica Frankenberg and Gary Orfield, The Resegregation of Suburban Schools: A Hidden Crisis in American Education. Review by Juliet F. Gainsborough

868 Kim L. Fridkin and Patrick J. Kenney, The Changing Face of Representation: The Gender of U.S. Senators and Constituent Communications. Review by Evelyn M. Simien

870 Daniel Q. Gillion, The Political Power of Protest: Minority Activism and Shifts in Public Policy. Review by Christopher Parker

871 Leslie McCall, The Undeserving Rich: American Beliefs about Inequality, Opportunity, and Redistribution. Review by Gregory A. Huber

872 Michael Storper, Keys to the City: How Economics, Institutions, Social Interaction, and Politics Shape Development. Review by Neil Kraus

873 Justin S. Vaughn and Jennifer R. Mercieca (Eds.), The Rhetoric of Heroic Expectations: Establishing the Obama Presidency.

Review by Roderick P. Hart

\section{COMPARATIVE POLITICS}

874 Eva Anduiza, Michael J. Jensen, and Laia Jorba, Digital Media and Political Engagement Worldwide: A Comparative Study.

Catie Snow Bailard, Democracy's Double-Edged Sword: How Internet Use Changes Citizens' Views of Their Government.

Review by Jessica L. Beyer

Elazar Barkan and Karen Barkey, Choreographies of Shared Sacred Sites: Religion, Politics and Conflict Resolution. Review by Ron E. Hassner

878 Jessica L. Beyer, Expect Us: Online Communities and Political Mobilization. Review by Seva Gunitsky

879 Michael Bratton, Power Politics in Zimbabwe. Review by Ngonidzashe Munemo

880 Melani Cammett and Lauren M. MacLean, The Politics of Non-state Social Welfare. Review by Tariq Thachil

Miguel A. Centeno and Agustin E. Ferraro, State and Nation Making in Latin America and Spain: Republics of the Possible.

Review by Joshua Simon

Russell J. Dalton, David M. Farrell, and Ian McAllister, Political Parties and Democratic Linkage: How Parties Organize Democracy. Review by Scott Morgenstern

885 Ariane Chebel d'Appollonia, Frontiers of Fear: Immigration and Insecurity in the United States and Europe. Review by Frank Foley

887 James Dawson, Cultures of Democracy in Serbia and Bulgaria.

Jessica Greenberg, After the Revolution: Youth, Democracy, and the Politics of Disappointment in Serbia. Review by Dan Mercea

889 Bedross Der Matossian, Shattered Dreams of Revolution: From Liberty to Violence in the Late Ottoman Empire. Review by M. Şükrü Hanioğlu

890 Renske Doorenspleet and Lia Nijzink, One-Party Dominance in African Democracies.

Rachel Beatty Riedl, Authoritarian Origins of Democratic Party Systems in Africa.

Sebastian Elischer, Poltical Parties in Africa: Ethnicity and Party Formation.

Review by Michele Kuenzi 
893 Roger Douglas, Law, Liberty, and the Pursuit of Terrorism.

Frank Foley, Countering Terrorism in Britain and France: Institutions, Norms and the Shadow of the Past. Review by Ariane Chebel d'Appollonia

Alain-G. Gagnon, AndrèLecours and Genevié ve Nootens, Contemporary Majority Nationalism. Review by Efraim Podoksik

Haider Ala Hamoudi, Negotiating in Civil Conflict: Constitutional Construction and Imperfect Bargaining in Iraq. Review by James D. Savage

Michael Herb, The Wages of Oil: Parliaments and Economic Development in Kuwait and the UAE. Review by Karen E. Young

Stanislav Markus, Property, Predation, and Protection: Piranha Capitalism in Russia and Ukraine. Review by Dinissa Duvanova

901 Marcus André Melo and Carlos Pereira, Making Brazil Work. Checking the President in a Multiparty System. Review by Alejandro Bonvecchi

902 Richard J. Samuels, 3.11: Disaster and Change in Japan. Review by Laurie A. Freeman

James D. Savage, Reconstructing Iraq's Budgetary Institutions: Coalition State Building after Saddam. Review by Haider Ala Hamoudi

905 Naunihal Singh, Seizing Power: The Strategic Logic of Military Coups. Review by Hicham Bou Nassif

906 Valerie Sperling, Sex, Politics and Putin: Political Legitimacy in Russia. Review by Gulnaz Sharafutdinova

Triadafilos Triadafilopoulos, Becoming Multicultural: Immigration and the Politics of Membership in Canada and Germany. Review by Claudia Finotelli

908 Thomas Waldman, Sultan Barakat, and Andrea Varisco, Understanding Influence: The Use of Statebuilding Research in British Policy. Review by Ericka A. Albaugh

\section{INTERNATIONAL RELATIONS}

910 Rebecca Adler-Nissen, Opting Out of the European Union: Diplomacy, Sovereignty and European Integration. Review by Mareike Kleine

911 Michael P. Colaresi, Democracy Declassified: The Secrecy Dilemma in National Security. Review by David Tucker

912 Catia Cecelia Confortini, Intelligent Compassion: Feminist Critical Methodology in the Women's International League for Peace and Freedom.

Review by Karen Garner

Sara B. Hobolt and James Tilley, Blaming Europe: Responsibility Without Accountability in the European Union. Review by Rebecca Adler-Nissen

915 Soeren Keil and Bernhard Stahl, The Foreign Policies of Post-Yugoslav States: From Yugoslavia to Europe. Review by Elton Skendaj

Friedrich Kratochwil, The Status of Law in World Society: Mediations on the Role and Rule of Law. Review by Christopher N. J. Roberts

918 Steven Livingston and Gregor Walter-Drop, Bits and Atoms: Information and Communication Technology in Areas of Limited Statehood.

Review by Benjamin M. Jensen

919 Sonia Ben Ouagrham-Gormley, Barriers to Bioweapons: The Challenges of Expertise and Organization for Weapons Development. Review by David W. Kearn

Brian C. Rathbun, Diplomacy's Value: Creating Security in 1920s Europe and the Contemporary Middle East. Review by Eric Grynaviski

922 Mathias Risse, On Global Justice. Review by Richard Vernon

923 Timothy Melley, The Covert Sphere: Secrecy, Fiction, and the National Security State.

Rahul Sagar, Secrets and Leaks: The Dilemmas of State Secrecy. Review by David Grondin

Review index 


\section{Philosophy of Perspectives on Politics}

Perspectives seeks to nurture a political science public sphere, publicizing important scholarly topics, ideas, and innovations, linking scholarly authors and readers, and promoting broad reflexive discussion among political scientists about the work that we do and why this work matters.

A full-length copy of the journal's editorial philosophy appears in Perspectives on Politics 8(1): 7-10 and also on the web at http://www.apsanet.org/content_44375.cfm.

\section{Submission and Review}

For submission guidelines, please see http://www.apsanet.org/content_44360.cfm.

Our editorial team discusses all submissions. Those that seem promising are evaluated by several external reviewers - with full confidentiality on both sides - and then accepted, returned for further revisions, or declined with suggestions of more appropriate venues for publication.

\section{CONTACT INFO}

Perspectives on Politics

Department of Political Science

1100 E. 7th St

Woodburn Hall 210G

Indiana University

Bloomington, IN 47405

Perspectives: perspectives@apsanet.org

Book Reviews: reviews@indiana.edu

\section{Perspectives on Politics}

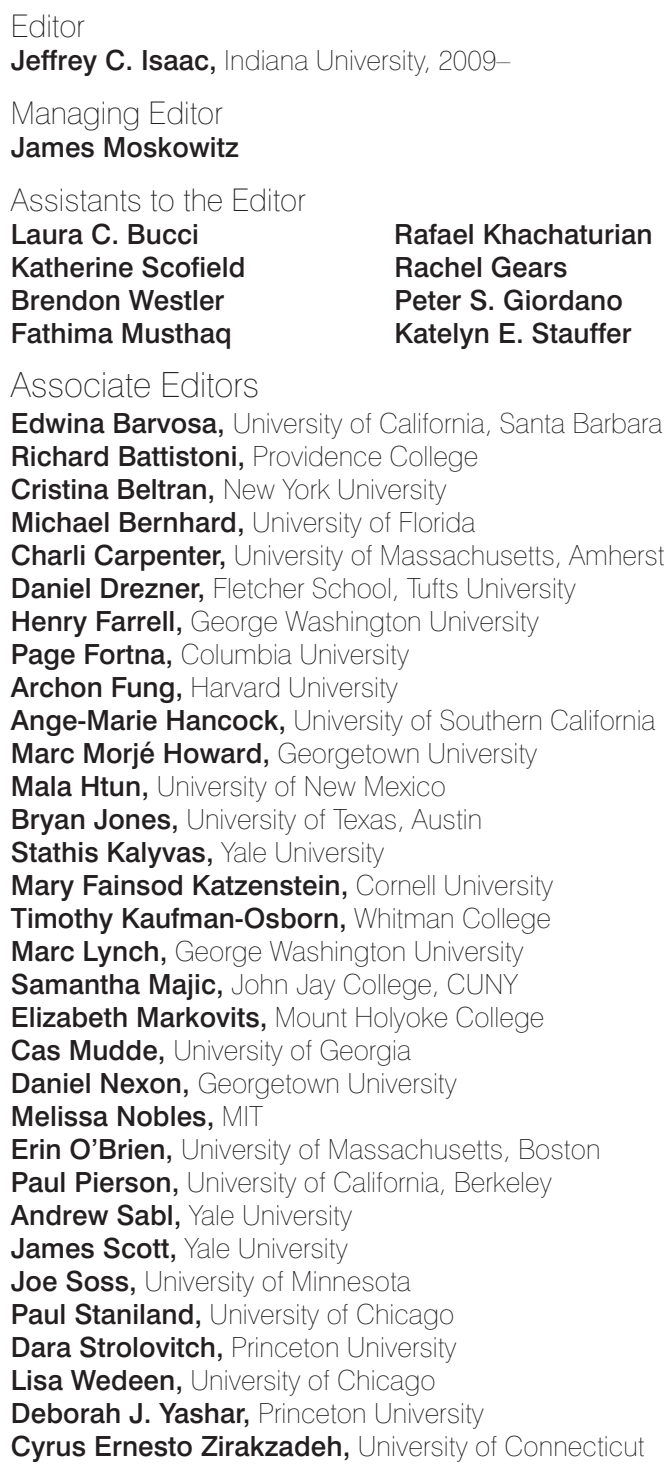

Association Office Address and Membership Information: American Political Science Association individual membership dues are as follow: Regular members with income $\$ 200,000$ + $\$ 320 ; \$ 135,000-\$ 199,999, \$ 271 ; \$ 100,000-\$ 134,000$ \$241; \$80,000-\$99,999, \$207; \$60,000-\$79,999, \$186 $\$ 50,000-\$ 59,999, \$ 170 ; \$ 40,000-\$ 49,999$, $\$ 145$; less than $\$ 40,000, \$ 98$; Student members, $\$ 45$; Retired members with income $\$ 25,000+$, \$66; Retired members with income less than $\$ 25,000, \$ 40$; Life members: $\$ 3,000$; Unemployed members: \$45; Associate member with one journal selection, \$62. The amount of the dues allocated for a subscription is $\$ 6.75$ for an individual membership. Changes of address for members should be completed online or mailed to the APSA membership office at: APSA, 1527 New Hampshire Avenue, N.W., Washington, DC 20036

Subscription, Publishing, and Advertising Office Address: Cambridge University Press, 32 Avenue of the Americas, New York, NY 10013; and (for correspondents outside the United States, Canada, and Mexico) Cambridge University Press, Journals Fulfillment Department, UPH, Shaftesbury Road, Cambridge CB2 8BS, England.

Subscription Information: Perspectives on Politics (ISSN 15375927) is published quarterly, in March, June, September, and December, by Cambridge University Press for the American Political Science Association. Annual institutional electronic-only subscription rate (2015) is US\$1119 in the United States, Canada, and Mexico; £625 elsewhere. Annual institutional print-andelectronic subscription rate (2015) is US\$1297 in the United States, Canada, and Mexico; £716 elsewhere. Perspectives on Politics is sold only as part of a joint subscription with the American Political Science Review and PS: Political Science \& Politics. Single part rate (2015) is US\$151 in the United States, Canada, and Mexico; £85 elsewhere. Periodicals postage rate paid at New York, NY, and additional mailing offices. Postmaster: Send address changes to Perspectives on Politics, Cambridge University Press, 100 Brook Hill Drive, West Nyack, NY 10994-2133, U.S.A

\section{(c) American Political Science Association 2015.}

All rights reserved. No part of this publication may be reproduced, in any form or by any means, electronic, photocopying, or otherwise, without permission in writing from Cambridge University Press. Policies, request forms, and contacts are available from: http://www.cambridge.org/rights/permissions/ permission.htm

Permission to copy (for users in the U.S.A) is available from the Copyright Clearance Center, http://www.copyright.com, email: info@copyright.com.

Advertising: Perspectives on Politics has a circulation of 16,000. For information on advertising rates and mechanical requirements, contact Advertising Coordinator, Cambridge University Press, 32 Avenue of the Americas, New York, NY 10013. (212) 337-5000.

Composition: TNQ Books and Journals Pvt. Ltd., Chennai, India.

Printing and Distribution: The Sheridan Press, Hanover, PA. 


\section{About APSA}

Founded in 1903, the American Political Science Association is the leading professional organization for the study of political science and serves more than 15,000 members in over 80 countries. With a range of programs and services for individuals, departments, and institutions, APSA brings together political scientists from all fields of inquiry, regions, and occupational endeavors within and outside academe in order to expand awareness and understanding of politics.

The direct advancement of knowledge is at the core of APSA activities. We promote scholarly communication in political science through a variety of initiatives including publishing three distinguished journals: American Political Science Review, Perspectives on Politics, and PS: Political Science and Politics.

\section{Officers}

\section{PRESIDENT}

Rodney E. Hero

University of California, Berkeley

\section{PRESIDENT-ELECT}

Jennifer Hochschild

Harvard University

\section{VICE-PRESIDENTS}

\section{E. J. Dionne, Jr.}

Georgetown University

Brookings Institution

Joanne Gowa

Princeton University

Fredrick C. Harris

Columbia University

\section{TREASURER}

Kathleen Thelen

Massachusetts Institute of Technology

\section{SECRETARY}

Linda L. Fowler

Dartmouth College

\section{PROGRAM CO-CHAIRS}

Layna Mosley

University of North Carolina,

Chapel Hill

Alvin Bernard Tillery

Northwestern University

\section{EDITOR-IN-CHIEF, APSR}

John Ishiyama

University of North Texas

\section{EDITOR-IN-CHIEF, \\ PERSPECTIVES}

Jeffrey C. Isaac

Indiana University

\section{EXECUTIVE DIRECTOR}

Steven Rathgeb Smith

American Political Science Association

\section{Council}

\section{3-2015}

Amrita Basu

Amherst College

Kenneth R. Benoit

London School of Economics

Christine Di Stefano

University of Washington

James N. Druckman

Northwestern University

Hank C. Jenkins-Smith

University of Oklahoma

David C. Kang

Universtiy of Southern California

John M. Sides

George Washington University

Evelyn M. Simien

University of Connecticut

\section{4-2016}

Michelle D. Deardorff

University of Tennessee,

Chattanooga

Maria C. Escobar-Lemmon

Texas A \& M University

Frances E. Lee

University of Maryland, College

Park

David Lublin

American University

Marc Lynch

George Washington University

Tasha Philpot

University of Texas, Austin

David Stasavage

New York University

Mark E. Warren

University of British Columbia

\section{Former APSA Presidents}

Frank J. Goodnow

Albert Shaw

Frederick N. Judson

James Bryce

A. Lawrence Lowell

Woodrow Wilson

Simeon E. Baldwin

Albert Bushnell Hart

W. W. Willoughby

John Bassett Moore

Ernst Freund

Jesse Macy

Munroe Smith

Henry Jones Ford

Paul S. Reinsch

Leo S. Rowe

William A. Dunning

Harry A. Garfield

James W. Garner

Charles E. Merriam

Charles A. Beard

William Bennett Munro

Jesse S. Reeves

John A. Fairlie

Benjamin F. Shambaugh

Edward S. Corwin

William F. Willoughby

Isidor Loeb

Walter Shepard

Francis W. Coker

Arthur N. Holcombe

Thomas Reed Powell

Clarence A. Dykstra

Charles Grove Haines

Robert C. Brooks

Frederic A. Ogg

William Anderson

Robert E. Cushman

Leonard D. White

John Gaus

Walter F. Dodd

Arthur W. MacMahon

Henry R. Spencer

Quincy Wright

James K. Pollock

Peter H. Odegard

Luther Gulick

Pendleton Herring

Ralph J. Bunche

Charles McKinley

Harold D. Lasswell

E. E. Schattschneider

V. O. Key, Jr.

R. Taylor Cole

Carl B. Swisher
Emmette S. Redford

Charles S. Hyneman

Carl J. Friedrich

C. Herman Pritchett

David B. Truman

Gabriel A. Almond

Robert A. Dahl

Merle Fainsod

David Easton

Karl W. Deutsch

Robert E. Lane

Heinz Eulau

Robert E. Ward

Avery Leiserson

Austin Ranney

James MacGregor Burns

Samuel H. Beer

John C. Wahlke

Leon D. Epstein

Warren E. Miller

Charles E. Lindblom

Seymour Martin Lipset

William H. Riker

Philip E. Converse

Richard F. Fenno

Aaron B. Wildavsky

Samuel P. Huntington

Kenneth N. Waltz

Lucian W. Pye

Judith N. Shklar

Theodore J. Lowi

James Q. Wilson

Lucius J. Barker

Charles O. Jones

Sidney Verba

Arend Lijphart

Elinor Ostrom

M. Kent Jennings

Matthew Holden, Jr.

Robert O. Keohane

Robert Jervis

Robert D. Putnam

Theda Skocpol

Susanne Hoeber Rudolph

Margaret Levi

Ira Katznelson

Robert Axelrod

Dianne M. Pinderhughes

Peter Katzenstein

Henry E. Brady

Carole Pateman

G. Bingham Powell, Jr.

Jane Mansbridge

John H. Aldrich

\section{APSA




\section{PS: Political Science and Politics}

\section{SPECIAL ISSUE!}

Let's Be Heard!

How to Better Communicate Political Science's Public Value

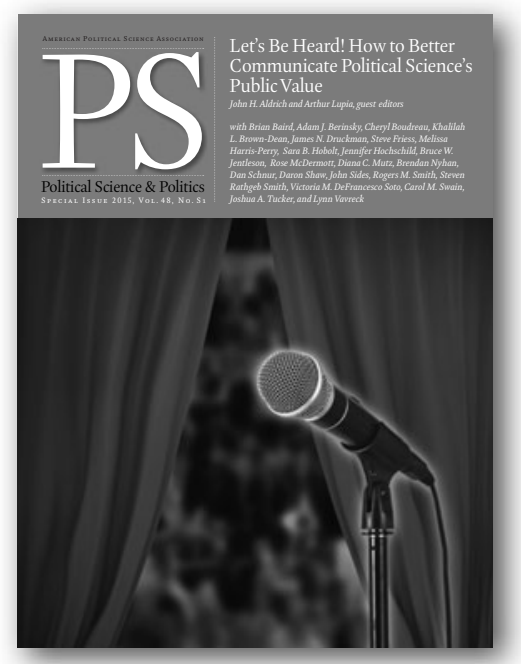

Political science is at a crossroads. The knowledge that it produces is more diverse and valuable than ever before - yet many audiences do not understand why or how political science is beneficial. Moreover, the rise of the Internet has changed the kinds of information that people seek. For many scholars, the question has become:

\section{"How do we make our knowledge accessible and} relevant to others while still retaining our high standards of scholarship and teaching?"

With this question in mind, APSA commissioned a Task Force on Public Engagement. Its leaders John $\mathrm{H}$. Aldrich and Arthur Lupia solicited constructive ideas from a diverse group of 21 experienced and knowledgeable academics and public figures. Let's Be Heard! makes these ideas available to everyone. Because of the topic's timeliness, the APSA and Cambridge University Press have agreed to make the special issue available for free at Cambridge Journals Online or visit www.apsanet.org/letsbeheard.

Let's Be Heard! is organized into three sections: Section I includes in-depth interviews with publicly engaged political scientists and practitioners; Section II examines how to change the profession's incentives for serving others; and Section III considers new

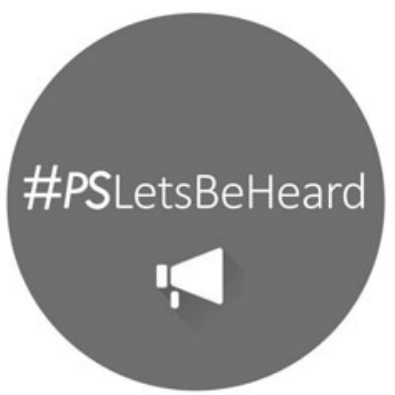
ideas, approaches, and avenues toward broadcasting the value of political science. The contributors contend that political science can offer immense, life changing value to society, but its ability to have this impact depends on its ability to communicate its knowledge effectively. Let's be heard! 